\title{
Assessment of Solid Waste from Cruise Ships in the Port of Split
}

\author{
Merica Sliškovića, Helena Ukića, Katja Božićb
}

The aim of this paper is to assess the quantity of solid waste in the port of Split produced by cruisers during the past five years. The increased number of cruising guests in the port of Split is associated with more marine litter produced and directly increases a potential impact on the marine environment. To sustainably manage its resources, the city of Split should carefully consider the positive and negative effects of the cruising industry, set up a quality control system in cruising and consider how potential profit impacts on the environment and natural resources.

\section{KEY WORDS}

Marine environment pollution

$\sim$ Port of Split

$\sim$ Solid waste

$\sim$ Preservation of environment

$\sim$ Cruising industry a. University of Split, Faculty of Maritime Studies, Split, Croatia

e-mail: merica.sliskovic@pfst.hr

b. Plovput d.o.o., Split, Croatia

e-mail: katja.bozic@plovput.hr

\section{INTRODUCTION}

Marine litter or debris is defined as any persistent, manufactured or processed solid material discarded, disposed of or abandoned in the marine and coastal environment. Marine litter consists of items that have been made or used by people and deliberately discarded into the sea or rivers or on beaches; brought indirectly to the sea with rivers, sewage, storm water or winds; accidentally lost, including material lost at sea in bad weather (fishing gear, cargo); or deliberately left by people on beaches and shores. (UNEP, 2005).

Marine litter produces a wide variety of negative environmental, economic, safety, health and cultural impacts. Some types of marine litter has a very slow rate of decomposition, leading to a gradual, but significant accumulation in the coastal and marine environment. (Jeftić et al., 2009).

In 2009, 498,818 volunteers picked up 7.4 million pounds of marine debris in 108 countries around the world. They removed marine litter from more than 21,000 kilometres of coastline and waterways collecting more than 6.2 million pieces of marine litter, weighing over 4,000 tonnes. Almost 58 percent of the marine litter found could be attributed to shoreline and recreational activities, such as beach-picnicking and general littering. (UNEP, 2016).

In general, public awareness of coastal and marine debris has increased dramatically over the past years. The main reasons for this are:

- Legislation on bathing water quality and waste water treatment

- Blue Flags, best beach guides and the like which have influenced users' choices as to where to bathe, etc., have informed and empowered the public choice Increasing campaigns by pressure groups have kept the subject in the public eye 
- An increase in recreational maritime activities has drawn the attention of more people to the quality of local coasts and sea

- An increase in contamination stories - whether it is cancerous fish, oiled seabirds, dying seals, washed up munitions or debris on beaches - has demonstrated that, despite Government legislation, the problem of marine pollution is a growing one. (Hall, 2000).

The Mediterranean Sea is one of the biggest tourist regions in the world. Tourist revenues are of significant socioeconomic importance for the coastal regions. Many of the tourist destinations are concentrated along the coast, with a heavy dependence on the marine environment. (Jeftić et al., 2009).

The main Adriatic Sea sources of marine litter, on the Croatian coast, can originate from merchant shipping, ferries and cruise liners, fishing vessels, military fleets and research vessels, pleasure craft, offshore oil and gas platforms, fish farming installations... The land based sources may usually occur from municipal landfills, discharge of untreated municipal sewage, including storm water (including occasional overflows), solid waste from landfills, and untreated waste water, sources along rivers and canals, tourism ...

\section{MARINE LITTER AND ACCOMPANYING LEGISLATION FOR POLLUTION PREVENTION}

Within the framework of the Convention for the Protection of the Mediterranean Sea against Pollution (Barcelona Convention, 1976), the Mediterranean countries adopted the Protocol for the Protection of the Mediterranean Sea against Pollution from landbased sources (Mediterranean Protocol, 1996).

Solid waste disposal prohibitions are very strictly settled in "Special Areas" for the purposes of Annex V of the MARPOL 73/78 Convention - The International Convention for the Prevention of Pollution from Ships. (MARPOL 73/78).

From 1 May 2009, Special Area of MARPOL Annex V for the Mediterranean (MARPOL Annex V) prohibits, for all ships, disposal of all plastics and all other garbage. More specifically, the disposal of the following is prohibited: plastics, including but not limited to synthetic ropes, synthetic fishing nets and plastic garbage bags; all other garbage, including paper products, rags, glass, metal, bottles, crockery, dunnage, lining and packing materials. Vessels must dispose of garbage ashore into appropriate reception facilities. If suitable facilities are not available, the garbage must be retained on board until the next port or discharged when the vessel is outside the special area.

The revised MARPOL Annex $\mathrm{V}$ with an entry into force date of 1 January 2013, prohibits the discharge of all types of garbage into the sea unless explicitly permitted under the Annex. Also, guidelines have been developed taking into account the regulations set forth in MARPOL Annex V. The purpose of these guidelines is to provide guidance to governments, ship owners, ship operators, ships' crews, cargo owners, port reception facility operators and equipment manufacturers. The guidelines (MEPC, 2012) are divided into the following six sections that provide a general framework upon which governments can formulate programmes:

I. Introduction;

II. Garbage management;

III. Management of cargo residues of solid bulk cargoes;

IV. Training, education and information;

V. Port reception facilities for garbage; and

VI. Enhancement of compliance with MARPOL Annex V.

Recognizing that the Annex $V$ regulations continue to restrict the discharge of garbage into the sea, require garbage management for ships, and that garbage management technology continues to evolve, it is recommended that governments and the IMO continue to gather information and review these guidelines periodically (MEPC, 2012).

1.4 Regulation 8 of MARPOL Annex $\mathrm{V}$ provides that Governments must ensure the provision of adequate port reception facilities for garbage from ships and should facilitate and promote their use. All ship owners and operators should minimize taking onboard material that could become garbage. Ship-specific garbage minimization procedures should be included in the Garbage Management Plan. It is recommended that manufacturers, cargo owners, ports and terminals, ship owners and operators and governments consider the management of garbage associated with ships' supplies, provisions, and cargoes as needed to minimize the generation of garbage in all forms (MEPC, 2012).

Compliance with MARPOL Annex $\mathrm{V}$ involves personnel, equipment and procedures for collecting, sorting, processing, storing, recycling, reusing and discharging garbage. Economic and procedural considerations associated with these activities include storage space requirements, sanitation, equipment and personnel costs and in port garbage service charges (MEPC, 2012). Procedures for handling ship-generated garbage are divided into four phases: collection, processing, storage, and discharge.

Regarding to distribution of marine litter a lot of actions have been taken nationally and internationally, but it is still an on-going process.

\section{CRUISING FACTS ABOUT THE PORT OF SPLIT}

The town of Split lies on the Adriatic coast, central Dalmatia. It is the administrative centre of the Split-Dalmatia County. Split is the largest city in Dalmatia, second largest city in Croatia, according to the latest census conducted in 2011 Split has 178,102 inhabitants. The port of Split is one of the 
largest passenger harbours in the Mediterranean and second largest Croatian cargo harbour, after Rijeka. Since 1979 the entire historical core of Split with Diocletian's palace has been listed as UNESCO World Heritage.

The city of Split, as the second major town of the Republic of Croatia has become a popular stop in the Mediterranean cruise ship routes as the cultural and historical centre of the Dalmatia County. In the course of only one day, five cruise ships are known to dock in the port, which amounts to approximately 12,000 people being let to the narrow streets of the city.

According to the Port of Split Authority, last year 262 cruise ships visited Split. Just for comparison, in the year before, 2014,

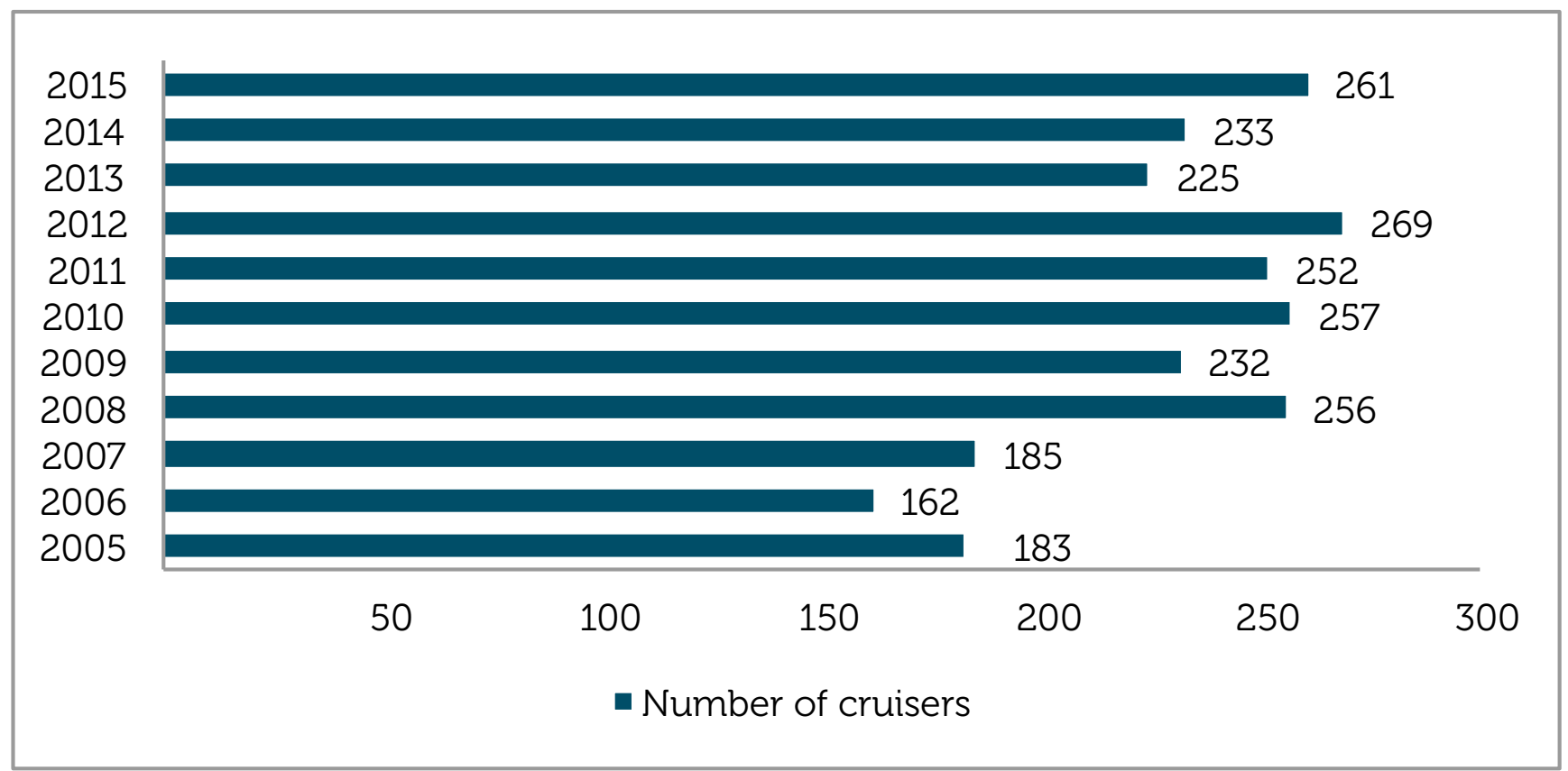

Figure 1.

Number of cruise ships arrived at the port of Split between years 2005 to 2015 .

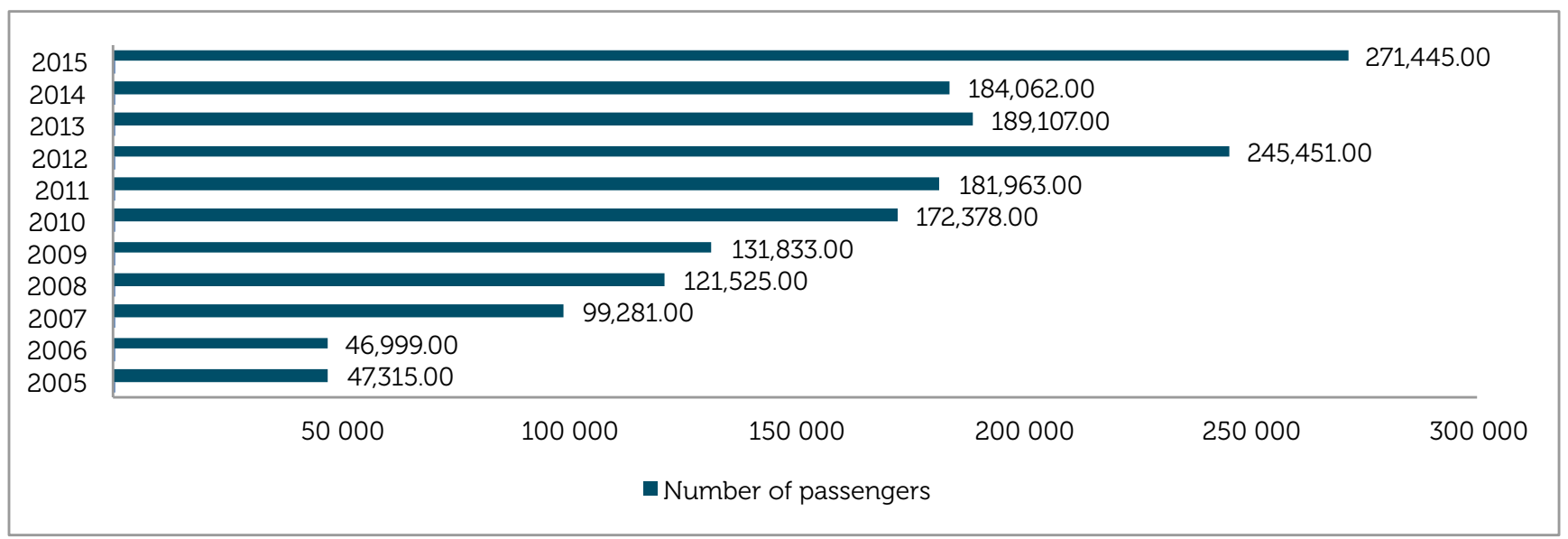

Figure 2.

Number of cruise ships and number of passengers arrived at Port of Split between years 2005 to 2015. 
233 "floating hotels" visited Split. For this year the Port of Split Authority announced 290 cruisers that have already registered, but this figure will surely increase by the end of the year. New docks are also planned for large ships, although no consensus was reached as to whether such a large number of visitors is necessary for Split and whether it is even cost effective considering that these are mainly day guests who do not spend much.

\section{PROTOCOLS FOR WASTE COLLECTION IN THE PORT OF SPLIT AREA}

The port of Split has three concession holders for the service of collecting mixed waste in 2015: Čistoća d.o.o., Split Tours d.d. and In Capita d.o.o.

The protocol for waste collection from vessels in the port of Split defines activities - the liquid waste can be accepted at anchor (only in Split), but only to the amount of $5 \mathrm{~m}^{3}$. Price for this specific service for anchored vessels increases for additional $1 \mathrm{~m}^{3}$ by $€ 55.00$, and for the Croatian flagged ships VAT has to be added to the price. For solid waste, the total minimum amount (sum) cannot be less than $100 \mathrm{~kg}$. All the waste must be in appropriate containers marked in accordance with MARPOL and the international label waste (waste code). Additional packaging and labelling is calculated at $0.15 € / \mathrm{kg}$ for foreign flag ships. The service price for solid waste on weekends and holidays is $30 \%$ higher (Port of Split Authority, 2016).

\section{CALCULATION OF SOLID WASTE LOADS}

A detailed analysis of the harmful effects of cruise ships in the port of Dubrovnik, which is the leading port in the number of passengers, is provided by (Carić, 2010a).

Using the same methodology for the calculation of the harmful effects, in part relating to solid waste, i.e. waste that cruise ships produce in the area of the port of Split, calculation of the amount of solid waste in kilograms is given. It is calculated that a passenger on a cruise ship capacity of 3,000 passengers produces $4 \mathrm{~kg}$ of solid waste daily (Carić, 2010b). The amount of the daily produced $4 \mathrm{~kg}$ of solid waste multiplied by an average day stay and the number of passengers gives the total amount of the solid waste for the period of 2010-2015. Average day stay in the city of Split is nine hours, i.e. 0.375 day (Port of Split Authority, 2016). It is important to note that the city of Split, only in the past few years recorded a significant growth in the number of cruise ships and passengers. The port of Split in the past 5 years received only a dozen of cruise ships that have a capacity of over 3,000 passengers. To view the assessment of the amount of waste, data on the number of passengers from cruise ships that have a capacity of over 2,000 passengers are used, so we must take into account the differences in the smaller percentage.

Also, it is important to note that the smaller cruise ships produce and dispose of waste that produces harmful effects on the environment, which is not included in the calculation.

Table 1.

Calculation of solid waste loads from cruise ships of 2,000 passenger capacity and more.

\begin{tabular}{|c|c|c|}
\hline Year & $\begin{array}{l}\text { Number of cruise ship guests } \\
\text { ( } 2,000 \text { passenger capacity and more) }\end{array}$ & Solid waste loads (kg) \\
\hline 2010 & 58,085 & 92,936 \\
\hline 2011 & 67,845 & 108,552 \\
\hline 2012 & 122,037 & $195,259.2$ \\
\hline 2013 & 70,433 & $112,692.8$ \\
\hline 2014 & 90,970 & 145,552 \\
\hline 2015 & 63,484 & $101,574.4$ \\
\hline 2010-2015 & 472,854 & $756,566.4$ \\
\hline
\end{tabular}

As already pointed out, there are no quality management policies for the waste disposal in the port area of Split, and port authorities do not collect separate data on waste collected from cruise ships. According to the available data from one of the three concessionaires in charge of waste collection, it is clear that there is a significant increase in the weight of mixed waste in the past five years. Comparing the calculated data in Table 1 with the amount of discharged waste shown in Figure 3, a huge difference in waste quantity is noticed. The potential impact on difference of discharged and calculated waste can be found in the fact that port of Split traffic annually reaches the number of approx. 4.5 million passengers and 650 thousand vehicles, and national and international traffic in the port have been continuously increasing, showing further growing tendency. It is important to emphasise that the increase in the number of cruise ships in the port of Split also significantly contributes to the increase of mixed waste amount. 


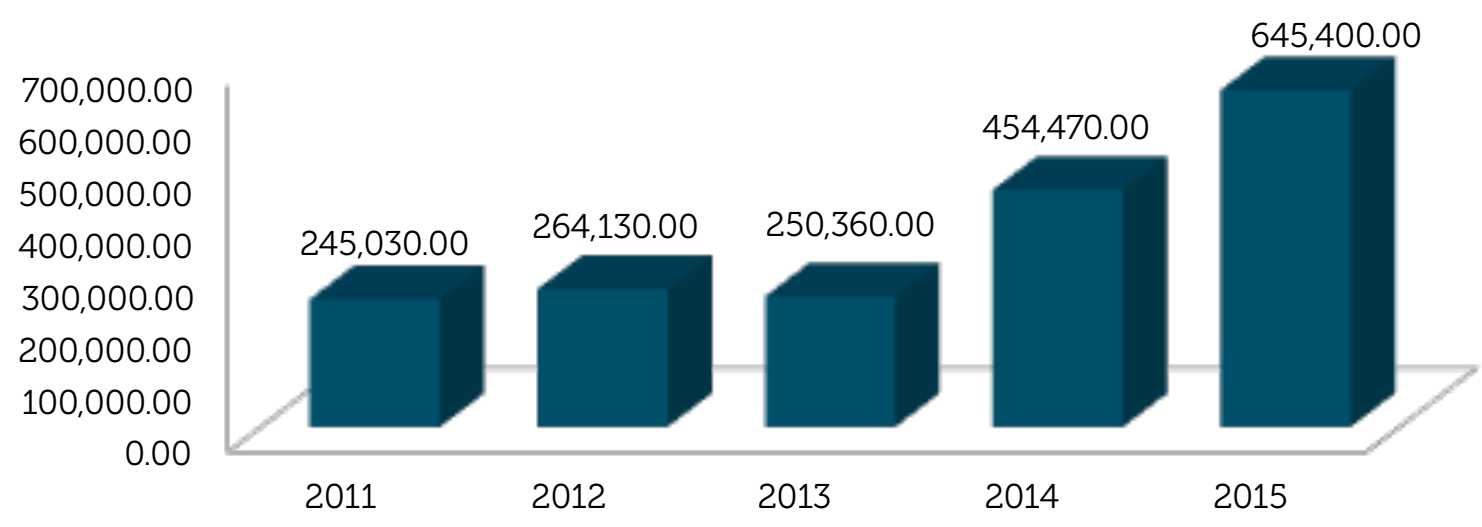

- Amount of discharged waste $(\mathrm{kg})$

Figure 3.

Amount of waste discharged in the port of Split area for period 2011-2015.

At all the levels of cruising industry as a nautical tourism phenomenon, the development of cruising as well as all the factors contributing to its successful development should clearly be formulated. It should clearly define goal, i.e. answer the question what the goal of specific entity regarding cruising is, what the profit is, both for cruise ships and cruise companies. Profit is the goal, but profit has to be ensured for a long period in terms of sustainable development. This means that strategic planning and strategic thinking in general must guarantee the future of cruising (Luković and Božić, 2010).

\section{CONCLUSION AND MEASURES PROPOSED BY THIS ARTICLE}

The Republic of Croatia in general has a lot of open issues regarding waste disposal, and problems are even bigger in tourist areas during the high season. An increase in the recreational maritime activities in the port of Split area, especially in the past few years poses a growing threat to the marine and coastal environment. Due to this fact, a large quantity of waste created by cruise ships, yachts and small boats can be expected.

As the port of Split is becoming one of the top cruising ports in Croatia, this paper highlights the potential threat to the marine environment by calculating only the solid waste from cruise ships. The calculation of solid waste is only taken into account because there are no quality management policies for the waste disposal in the port area of Split, and the port authorities do not collect separate data on the waste collected from cruise ships.

The fact that the port of Split is one of the top five
Mediterranean passenger ports, a large amount of mixed waste is expected. The analysed data in the port of Split area show a significant increase in the weight of mixed waste in the past five years. From 2005 up to date, the number of cruise guests is five times higher, which consequently leads to the increment of produced waste. The calculation of solid waste from 2010 to 2015 and the comparison with passenger numbers is in accordance with the observation regarding increment of produced waste.

In order to minimize the influence of produced waste, the following measures are proposed:

- To design and establish a quality control system in cruising; - To improve cooperation of all participants, including port authorities, local authorities and the government in order to find solutions and a proper management plan for waste disposal;

- To create a base for collection and comparison of data received by all concession holders regarding waste disposal;

- To establish a proper waste management for quality collecting of garbage produced and separated on board.

\section{REFERENCES}

Barcelona Convention, (1976), Convention for the Protection of the Mediterranean Sea against Pollution, available at: http://www.unepmap.org/index.php? $m$ odule $=c$ ontent2\&catid=001001004, [accessed 12 February 2016].

Carić H., (2010a), Cruising Tourism Environmental Impacts: Case Study of Dubrovnik, (Croatia). In: Micallef, A. (ed.), MCRR3-2010 Conference Proceedings, Journal of Coastal Research, Special Issue, No. 61, pp. 104-113., available at: http://www. jcronline.org/doi/pdf/10.2112/SI61-001.2, [accessed 2 February, 2016].,

http://dx.doi.org/10.2112/SI61-001.2 
Carić H., (2010b), Direct Pollution Cost Assessment Of Cruising Tourism In The Croatia Adriatic, Financial Theory and Practice, 34(2), pp. 161 - 180., available at: http://hrcak.srce.hr/file/81725 or http://www.fintp.hr/upload/files/ftp/2010/2/caric. pdf, [accessed 2 February, 2016].

Hall, K., (2000), Impacts of marine debris and oil; Economic and social costs to coastal communities, Kommunenes Internasjonale Miljorganisasjon (KIMO), available at: http://www.kimointernational.org/WebData/Files/Karensreport.pdf, [accessed 20 January, 2016].

Jeftic, Lj., Sheavly, S. and Adler, E., (2009), Marine Litter: A Global Challenge, United Nations Environment programme, available at: http://www.unep.org/pdf/unep_ marine_litter-a_global_challenge.pdf, [accessed 12 January, 2016].

Luković, T. and Božić, K., (2010), Seasonality - factor of crisis or development in cruise tourism, Proc. of the 2 nd International Cruise Conference, "The cruise industry - emerging issues, problems and solutions", Plymouth, England, February 18-20, pp. 23-27.

MARPOL ANNEX V Prevention of pollution by garbage from ship, Special area Mediterranean, available at: http://www.imo.org/en/OurWork/Environment/ SpecialAreasUnderMARPOL/, [accessed 8 January, 2016].
MARPOL (73/78), Prevention of Pollution by Garbage from Ships, Review of Annex V, available at: http://www.imo.org/blast/mainframe.asp?topic_id=297, [accessed 8 January, 2016].

Mediterranean Protocol, (1996), Protocol for the Protection of the Mediterranean Sea Against Pollution from Land-based Sources, available at: http://www.unep.ch/ regionalseas/main/med/mlbspii.html, [accessed 8 January, 2016].

MEPC, (2012), The Marine Environment Protection Committee, Guidelines for the implementation of Marpol Annex V, Resolution MEPC.219(63), available at: http://www.imo.org/en/OurWork/Environment/PollutionPrevention/Garbage/ Documents/2014\%20revision/RESOLUTION\%20MEPC.219(63)\%20Guidelines\%20 for\%20the\%20Implementation\%20of\%20MARPOL\%20Annex\%20V.pdf, [accessed 8 February, 2016].

Port of Split Authority home page, available at: http://portsplit.com/en/, [accessed 1 February, 2016].

UNEP home page, available at: http://www.unep.org/regionalseas/marinelitter/ about/default.asp, [accessed 13 January, 2016].

UNEP, (2005), United Nations Environment Program, 2005. Marine Litter, an analytical overview., Kenya, available at: http:// www.unep.org/regionalseas/marinelitter/ publications/docs/anl_oview.pdf, [accessed 6 January, 2016]. 